\title{
New Distribution Records of the Bombay Leaf-toed Gecko, Hemidactylus prashadi Smith 1935 (Geklkonidae), from Maharashtra, India
}

Amit Sayyed ${ }^{1}$ and Abhijeet $\mathrm{Nale}^{2}$

${ }^{1}$ Wildlife Protection and Research Society, Maharashtra, India (amitsayyedsatara@gmail.com) ${ }^{2}$ Wildlife Protection and Research Society, Maharashtra, India

$\mathrm{T}^{\mathrm{h}}$ he Bombay Leaf-toed Gecko (Hemidactylus prashadi), which is endemic to the Western Ghats of India, is among the most poorly studied gekkonid species in India (Bauer et al. 2010). For many years, it was known only from near the type locality at Jog Falls (Smith 1935; Giri and Bauer 2006) but recent records have enlarged the known distribution, which now totals $50,000 \mathrm{~km}^{2}$ in Maharashtra, Goa, and Karnataka. In this area, the northernmost record is Dorle, Maharashtra, and the southernmost record comes from Jog Falls, Karnataka (Giri and Bauer 2006). However, distances between the records are large and whether populations are fragmented or intervening areas have not been sampled is not known. Although listed as being of
Least Concern on the IUCN Red List (Srinivasulu and Srinivasulu 2013), populations at some locations appear to be declining due to anthropogenic effects despite some records of these geckos on walls of human habitations and in palm plantations (Giri and Bauer 2006). In natural habitats, Bombay Leaf-toed Geckos live on trees and rocks in semi-evergreen forests at elevations of 15-1,500 m asl. Giri and Bauer (2006) described habitat partitioning in which juveniles live mainly on trees and adults chiefly on rocks and associated crevices.

Herein we report two localities for Hemidactylus prashadi from the northern Western Ghats of India. On 11 June 2019, we found an adult and a subadult in a cave at Devrukh,

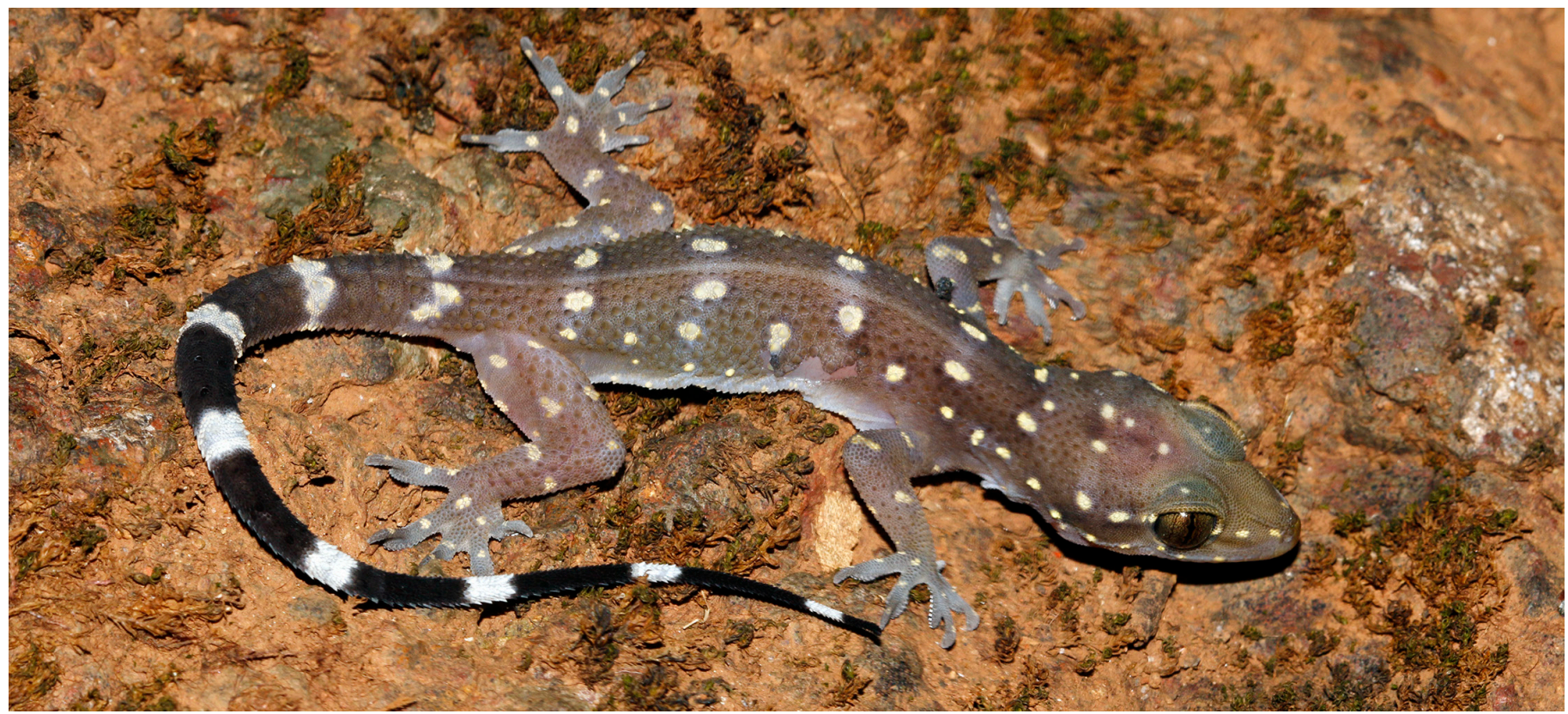

Fig. 1. A subadult Bombay Leaf-toed Gecko (Hemidactylus prashadi) in a cave in semi-evergreen forest in Devrukh, Maharashtra. Photographs by Amit Sayyed. 
Maharashtra (elev. 1,300 $\mathrm{m}$ asl), which is the northernmost record for the species. The adult was on the wall of the cave at dawn and escaped before we were able to take a photograph. The subadult specimen (Fig. 1) was on a rock in close proximity to the cave after sunset. We also found six individuals during a field survey on 28 December 2019 at the Rangna Fort, Kolhapur, Maharashtra (679 m asl). Four adults were on the fort and two others were on the wall of a cave (locally known as Shidhachi Gufa) $3 \mathrm{~km}$ from the fort.

Despite new records in recent years, the precise distribution and natural history of Hemidactylus prashadi remain largely unknown. We encourage additional surveys and field studies to better understand this relatively poorly known gecko.

\section{Acknowledgements}

We thank Dewendra Bhosle, Kiran Ahire, Rahul Thombre, Vikas Jagtap, Ashitosh Suryawanshi, Rahul Mandalik, Vijay Genjge, and team WLPRS for fieldwork.

\section{Literature Cited}

Bauer, A.M., T.R. Jackman, E. Greenbaum, V.B. Giri, and A. de Silva. 2010. South Asia supports a major endemic radiation of Hemidactylus geckos. Molecular Phylogenetics and Evolution 57: 343-352.

Giri, V. and A.M. Bauer. 2006. Notes on the distribution, natural history and variation of Hemidactylus prashadi Smith, 1935. Hamadryad 30: 55-60.

Smith, M.A. 1935. The Fauna of British India, including Ceylon and Burma. Reptilia and Amphibia. Vol. II.-Sauria. Taylor and Francis, London, UK.

Srinivasulu, C. and B. Srinivasulu. 2013. Hemidactylus prashadi. The IUCN Red List of Threatened Species 2013: e.T172638A1357072. <http://dx.doi. org/10.2305/IUCN.UK.2013-1.RLTS.T172638A1357072.en>. 